\title{
Kajian Waktu Irigasi pada Tanaman Selada (Lactuva Sativa) Organik Untuk Budidaya Tanaman dengan Naungan dan Tanpa Naungan di Yayasan Bina Sarana Bakti Cisarua Bogor
}

\author{
Study of Irrigation Time on Organic Lettuce (Lactuva Sativa) for \\ Shade and No Shade Cultivation at Bina Sarana Bakti Cisarua \\ Bogor Foundation
}

\author{
Desi Novalia, Muhammad Idrus, dan I Gde Darmaputra \\ Jurusan Teknologi Pertanian, Politeknik Negeri Lampung \\ Jl. Soekarno-Hatta, Rajabasa, Bandar Lampung 35144 Tel. (0721)703995
}

\begin{abstract}
The Bina Sarana Bakti Foundation (YBSB) implements an organic farming system, which is an agricultural management system with a terrace design with permanent beds that can ecologically (environmentally) improve land quality, provide stable and sustainable yields and income into the future. To provide water for plants so that organic farming can take place throughout the season, both in the rainy season and in the dry season, water reservoirs are built using existing water sources. Utilization of water in the cultivation of organic lettuce at the Bina Sarana Bakti Foundation is carried out with 2-level irrigation hose treatment, namely the interval of providing irrigation water for 3 days and 4 days. Data analysis used t test at 5\% real level. The results showed that the theoretical amount of water for lettuce at the Bina Sarana Bakti Foundation was 714 l/bed/season which was almost the same as the actual water use of lettuce with an interval of 3 days of irrigation water including additional liquid fertilizer from rabbit urine. + water in open land in shade is $720 \mathrm{l} / \mathrm{bed} / \mathrm{season}$, however, it is much lower than the interval of providing irrigation water for 4 days in open land without shade, namely 4,980 l/bed/season. The production of lettuce in shade with an interval of 3 days of $30.4 \mathrm{~kg} / \mathrm{bed} / \mathrm{season}$ was much greater than the production of lettuce without shade with an interval of 4 days of irrigation water, which was only $24.7 \mathrm{~kg} / \mathrm{bed} / \mathrm{season}$. The productivity of irrigation water for shaded lettuce with the provision of irrigation water at an interval of 3 days of irrigation is $42.22 \mathrm{~kg} / \mathrm{m}^{3}$, much higher and more effective than lettuce without shade with an interval of 4 days of irrigation which is only $4.96 \mathrm{~kg} / \mathrm{m}^{3}$.
\end{abstract}

Keywords: irrigation time interval, lettuce plants, no shade, shade, and water productivity.

Naskah ini diterima pada tanggal 4 Juni 2020, direvisi pada tanggal 18 Juni 2020 dan disetujui untuk diterbitkan pada tanggal 15 Agustus 2020

\section{PENDAHULUAN}

Sektor pertanian merupakan sektor yang mendapatkan perhatian cukup besar dari pemerintah dikarenakan peranannya yang sangat penting dalam rangka pembangunan ekonomi jangka panjang maupun dalam rangka pemulihan ekonomi bangsa. Peranan sektor pertanian adalah sebagai sumber penghasil bahan kebutuhan pokok, sandang dan papan, menyediakan lapangan 
kerja bagi sebagian besar penduduk, memberikan sumbangan terhadap pendapatan nasional yang tinggi, memberikan devisa bagi negara dan mempunyai efek pengganda ekonomi yang tinggi dengan rendahnya ketergantungan terhadap impor (multiplier effect), yaitu keterkaitan inputoutput antar industri, konsumsi dan investasi. Sektor pertanian juga dapat menjadi basis dalam mengembangkan kegiatan ekonomi perdesaan melalui pengembangan usaha berbasis pertanian yaitu agribisnis dan agroindustri. Dengan pertumbuhan yang terus positif secara konsisten, sektor pertanian berperan besar dalam menjaga laju pertumbuhan ekonomi nasional.

Upaya yang dilakukan untuk menjadikan sektor pertanian tetap berperan besar dalam menjaga laju pertumbuhan ekonomi nasional yang berkelanjutan diantaranya adalah pertanian organik. Yayasan Bina Sarana Bakti (YBSB) memiliki sistem pertanian organik salah satunya adalah pertanian organik lahan permanen. Penerapan sistem ini merupakan suatu sistem pengelolaan pertanian dengan desain memanfaatkan lahan dan dibuat teras dan dibentuk bedengan secara permanen yang didasarkan pada prinsip-prinsip ekologi (lingkungan) yang dapat meningkatkan kualitas lahan, memberikan hasil dan pendapatan yang stabil, sehingga berkelanjutan sampai kemasa depan.

Sistem ini membantu untuk memahami serta menciptakan hubungan yang harmonis antara alam dan manusia yang saling membutuhkan untuk jangka waktu yang berkelanjutan. Desain lahan permanen merupakan sentuhan teknologi modern dalam pengelolaan lahan, hal ini merupakan cara yang holistik, ramah lingkungan dan yang terpenting alam tetap terjaga. Dalam usahanya untuk penyediaan air bagi tanaman agar pertanian organik dapat berlangsung sepanjang musim baik di musim hujan maupun di musim kemarau, bangunan-bangunan air dibangun untuk memanfaatkan sumber-sumber air yang ada. Salah satu tujuan dari bangunan air tersebut, untuk mencegah kekurangan air pada saat musim kemarau.

Pada prinsipnya pertanian organik lebih bersahabat atau selaras dengan lingkungan serta tidak merusak dan mencemarkan lingkungan bahkan merupakan sistem pertanian yang efisien apabila dilihat dari perbandingan antara output persatuan unit input, meskipun dilihat dari output per hektar nya masih lebih rendah dari pada sistem pertanian kovensional.

Salah satu tanaman yang dibudidayakan secara organik di Yayasan Bina Sarana Bakti (YBSB) adalah Selada. Selada umumnya dimakan mentah dan dibuat salad atau disajikan dalam berbagai bentuk masakan Eropa atau Cina, selada jarang sekali dimasak karena mempunyai rasa yang kurang enak dan sulit di cerna. Selada mengandung gizi yang cukup tinggi terutama sumber mineral. Menurut Rukmana (2004) kandungan dan komposisi selada yakni kalori 15 kal, protein 1,2 gr, lemak 0,2 gr, karbohidrat 2,9 gr, kalsium $22 \mathrm{mg}$, fosfor $25 \mathrm{mg}$, zat besi 0,5 gr, vitamin A 540 S.I, vitamin B1 0,04 mg, Vitamin C 8 mg, dan air 94,8 gr dalam $1 \mathrm{~kg}$ selada.

Selada mempunyai banyak manfaat dan mudah untuk dibudidaya serta prospeknya yang menjanjikan untuk memenuhi kebutuhan sayuran bagi masyarakat. Kegiatan budidaya selada secara organik merupakan suatu konsep yang dapat dilakukan mengingat semakin meningkatnya 
kesadaran masyarakat akan hidup sehat serta luasnya peluang pasar untuk pertanian organik.

Ketersediaan air untuk kebutuhan air tanaman harus selalu tercukupi dalam jumlah yang tepat dan pada waktu yang tepat. Kekurangan air pada tanaman akan menimbulkan tekanan (stress) pada tanaman dan bila kebutuhan air pada tanaman tidak terpenuhi, pada kondisi tertentu dapat mempengaruhi pertumbuhan dan hasil tanaman.

Pemberian air irigasi secara ekonomis (tepat waktu dan volume) sangat penting bagi pertumbuhan tanaman dimana air yang tersedia dalam tanah akan mudah diserap oleh tanaman sehingga tanaman tumbuh dan berproduksi dengan baik. Pemberian air irigasi pada tanaman selada di YBSB Cisarua Bogor masih dilakukan secara tradisional yaitu dengan menggunakan gembor yang dilakukan hampir setiap hari baik di musim kemarau maupun di musim hujan karena kebanyakan komoditas sayuran ditanam dalam bedengan-bedangan permanen yang diberi naungan plastik transparant. Dari uraian-uraian diatas penulis tertarik melakukan penelitian untuk mencari waktu pemberian irigasi yang baik bagi pertumbuhan selada di bawah naungan plastik transparan.

Selada merupakan tanaman yang tidak banyak membutuhkan sinar matahari dan pemberian air secara berlebih, sinar matahari dan pemberian air yang terlalu banyak mengakibatkan daun selada menjadi hancur dan menguning. Dalam perlakuan penelitian ini dilakukan dengan perbedaan antara tanaman selada dalam naungan dan tanaman selada tanpa naungan, guna untuk mengetahui jumlah kebutuhan air pada tanaman selada.

Idrus (2013) melaporkan bahwa produksi tanaman selada hidroponik dengan sistem irigasi tetes tipe orifis tanpa pompa rata-rata 130,31 g/tanaman lebih tinggi dibandingkan dengan sistem penyiraman manual yang hanya sebesar 97,29 g/tanaman. Jumlah pemakaian air tanaman selada dengan sistem irigasi tetes tipe orifis rata-rata 1,53 1/hari, sedangkan dengan metode manual disiram dengan gembor rata-rata 2,0 1/hari. Produktivitas larutan hara tanaman slada hidroponik dengan sistem irigasi tetes tipe orifis tanpa pompa sebesar $2,44 \mathrm{~kg} / \mathrm{m}^{3}$ adalah lebih tinggi dibandingkan dengan sistem penyiraman manual yang hanya sebesar $1,39 \mathrm{~kg} / \mathrm{m}^{3}$. Selanjutnya, Widiasari (2015) melaporkan bahwa dengan hidroponik metode nutrient film technique (NFT) produksi rata-rata selada Romain $166 \mathrm{~g} /$ tanaman dan jumlah pemakaian air 12,71 1/tanaman/musim dengan produktivitas air 13,60 kg/m ${ }^{3}$. Hal yang sama juga dilaporkan oleh Arismundar (2019) yang menyatakan bahwa produksi rata-tata selada Romain $124 \mathrm{~g} /$ tanaman dan jumlah pemakaian air rata-rata 10,17 1/tanaman/musim dengan produktivitas air rata-rata $12,23 \mathrm{~kg} / \mathrm{m}^{3}$.

Penelitian ini bertujuan (1) menghitung jumlah kebutuhan air secara teoritis dan jumlah pemakaian air secara aktual tanaman selada di Yayasan Bina Sarana Bakti, (2) Menghitung produktivitas air irigasi tanaman selada pada selang waktu irigasi yang berbeda. 


\section{METODE PELAKSANAN}

Penelitian dilaksanakan di Yayasan Bina Sarana Bakti, Pusat Pengembangan Pertanian Organik (Organic Development Center), yang berletak di Jl. Gandamanah, No. 74 Kampung Sampay, Dasa Tugu Selatan, Kecamatan Cisarua, Kabupaten Bogor, Jawa Barat. Bahan yang digunakan dalam penelitian benih selada Romain, pupuk kompos, dolomit, dan urine kelinci. Alat yang digunakan dalam penelitian meliputi garpu, cangkul, tebasan/sabit, timbangan, lori, penggaris dan kontainer.

Perlakuan penelitian yaitu selang waktu irigasi yang terdiri dari 2 level yaitu selang waktu irigasi 3 hari dan selang waktu irigasi 4 hari. Analisis data dilakukan dengan uji t pada taraf nyata $5 \%$.

Peubah yang diamati yaitu jumlah pemakaian air irigasi, produksi dan produktivitas air. Hal pertama yang dilakukan dalam teknik budidaya selada adalah persiapan lahan. Persiapan lahan dimulai dengan mempersiapkan bedengan untuk tanam. Di Yayasan Bina Sarana Bakti ukuran bedengan telah disesuaikan yaitu lebar $1 \mathrm{~m}$ dan panjang $10 \mathrm{~m}$ yang bertujuan untuk memudahkan dalam menghitung kebutuhan bibit selada dan pupuk kompos per bedengan.

Pengolahan tanah yang terdapat di Yayasan Bina Sarana Bakti yaitu dengan cara sistem pengarpuan, sistem double digging, dan sistem tanah cangkul rumput kubur (tancangrukup). Untuk tanaman selada digunakan sistem pengarpuan karena sistem perakarannya berkisar $25-50 \mathrm{~cm}$. Pengolahan tanah diawali dengan menggemburkan tanah menggunakan garpu bertujuan agar tanah lapisan atas (topsoil) dan tanah lapisan bawah (subsoil) tercampur dan dapat memperbanyak rongga udara dan sinar matahari yang masuk ke dalam tanah kemudian dilanjutkan dengan pemberian pupuk kompos lalu dicampur dan diratakan dengan tanah dibedengan yang telah di gemburkan.

Komposisi kompos yang ada di Yayasan Bina Sarana Bakti sebagai pupuk tanah terbuat dari limbah gulma/rumput, limbah media jamur dan kotoran ayam dengan perbandingan $1: 1: 2$. Dosis pemberian pupuk kompos $50 \mathrm{~kg} /$ bedengan.

Pada minggu kedua setelah tanam setiap bedengan tanaman selada diberikan/disiram dengan 20 liter urine kelinci yang telah dicampur dengan air. Pada minggu ketiga setelah tanam diberikan lagi 40 liter urine kelinci yang telah dicampur dengan air. Urine kelinci yang diberikan telah difermentasi selama dua minggu. Urin kelinci mengandung unsur makra dan unsur mikro dalam urin kelinci terdapat unsur $\mathrm{N}, \mathrm{P}$ dan $\mathrm{K}$ yang dapat membuat tanaman tumbuh dengan baik. Benih selada disemai dan dibibitkan dalam polybag yang telah diisi dengan campuran media tanah subur, pupuk kompos, dan pupuk kandang dari kotoran ayam yang telah dimatangkan selama 3 bulan. Kompos matang ditambahkan kapur dolomite untuk meningkatkan $\mathrm{pH}$ tanah. Bibit selada siap ditanam di bedengan setelah 3 minggu disemai di polybag. Bibit selada ditanam secara zig-zag dengan jarak tanam $20 \mathrm{~cm}$ × $20 \mathrm{~cm}$ sehingga pupulasi bibit selada 250 batang per bedengan. Penyiangan pada tanaman selada dilakukan dengan mencabut gulma atau rumput liar yang ada disekitar tanaman pada bedengan, dengan tujuan agar pertumbuhan tanaman selada dapat tumbuh 
dengan baik. Biasanya gulma akan tumbuh sekitar kurang lebih setelah 2 minggu setelah tanam, gulma yang berada di dalam bedengan dilakukan dengan mencabut, sedangkan gulma yang tumbuh diluar bedengan dilakukan dengan menggunakan alat tebasan. Gulma yang tumbuh diluar bedengan tidak dicabut karena berfungsi untuk menahan tanah agar tidak longsor.

Penyulaman dilakukan apabila tanaman selada rusak atau mati dan pertumbuhan tanaman yang tidak normal. Dengan tujuan untuk tetap menjaga hasil produksi pada tanaman.

Penyiraman dilakukan cara manual yaitu dengan menggunakan gembor ukuran 10 liter. Yayasan Bina Sarana Bakti mempunyai 3 sumber air, yaitu sumber air sungai, sungai air hujan, dan sumber air mata air. Penyiraman dilakukan dengan cara menyiram pada permukaan tanah hingga rata keseluruhan bagian bedengan. Pemberian air diberikan sejak tanaman berumur 1 hari. Pada penelitian ini, pemberian air di berikan sesuai dengan perlakuan selang waktu irigasi. Pemberian air berbeda-beda disetiap minggunya guna untuk menyesuaikan pertumbuhan tanaman. Perlakuan pemberian air irigasi selang waktu irigasi 3 hari pada tanaman selada dalam naungan, pada minggu pertama, kedua, ketiga, dan keempat diberikan air berturut-turut 155 liter, 160 liter, 235 liter, dan 110 liter. Perlakuan pemberian air irigasi selang waktu irigasi 4 hari pada tanaman selada tanpa naungan, pada minggu pertama, kedua, ketiga, dan keempat diberikan air berturut-turut 90 liter, 130 liter, 160 liter, dan 80 liter.

Jumlah air irigasi yang diberikan apakah sesuai atau tidak sesuai dengan kebutuhan air tanaman ?, maka perlu menghitung kebutuhan air teoritis tanaman selada. Kebutuhan air teoritis tanaman selada dapat dihitung dengan menggunakan metode Blaney Criddle sebagai berikut:

$$
\mathrm{ETo}=\mathrm{c}[\mathrm{p}(0,46 \mathrm{~T}+8)]
$$

Dimana:

ETo $=$ evapotranspirasi potensial $(\mathrm{mm} / \mathrm{hari})$

$\mathrm{T}=$ suhu harian rata-rata pada bulan tertentu $\left({ }^{\circ} \mathrm{C}\right)$

$\mathrm{p}=$ persentase harian rata-data dari total jam siang hari tahunan untuk bulan dan garis lintang tertentu, dapat diperoleh pada tabel $\mathrm{p}$.

$\mathrm{c}=$ faktor penyesuai yang tergantung pada rata-rata kelembaban udara relatif, lama penyinaran, dan

kecepatan angin siang hari.

Selanjutnya kebutuhan air konsumtif tanaman selada (ETc) dihitung dengan persamaan berikut:

$$
\mathrm{ETc}=\mathrm{kc} \text { ETo }
$$

Dimana:

$\mathrm{ETc}=$ evapotranspirasi tanaman $(\mathrm{mm} / \mathrm{hari})$

$\mathrm{kc}=$ koefisien tanaman tergantung pada tahap pertumbuhan tanaman

Pengelompokan kelembaban udara relatif $(\mathrm{RH})$, rasio lama penyinaran dan kecepatan angin dapat dilihat pada Tabel 1 . 
Tabel 1. Rata-rata kelompok RH, penyinaran $\mathrm{n} / \mathrm{N}$ dan kecepatan angin.

\begin{tabular}{lcccccc}
\hline \multicolumn{1}{c}{ Unsur iklim } & Rendah & Sedang & Tinggi & Kering & Basah & Keterangan \\
\hline RH Rata-rata $(\%)$ & $<20$ & $20-50$ & $>50$ & $<20$ & $>70$ & Blaney Criddle \\
\hline Ratio n/N & $<0,6$ & $0,6-0,8$ & $>0,8$ & - & - & Blaney Criddle \\
\hline & Ringan & Sedang & Kuat & Sangat Kuat & & \\
\hline Kecepatan & $<2$ & $2-5$ & $5-8$ & $>8$ & & Umum \\
Angin (U2) m/dt & & & & & & \\
\hline
\end{tabular}

Keterangan:

RH : Kelembaban udara relatif (\%)

$n$ : Lamanya penyinaran aktual (jam)

$N$ : Lama penyinaran maksimum yang mungkin terjadi (jam)

Pemanenenan tanaman selada (Lactuca Sativa L) dilakukan pada umur kurang lebih selama 30 hari setelah tanam. Pemanenan dilakukan dengan memotong pangkal batang tanaman menggunakan pisau secara hati-hati. Setelah itu hasil panen dikumpulkan kemudian disortir dan dikelompokkan sesuai kriteria yang ada di Yayasan Bina Sarana Bakti. Standar mutu hasil panen tanaman selada di Yayasan Bina Sarana Bakti dapat dilihat pada Tabel 2.

Tabel 2. Standar Mutu Tanaman Selada

\begin{tabular}{cll}
\hline No & \multicolumn{1}{c}{ Ciri-ciri } & Isi per kg \\
\hline 1 & Warna Hijau muda segar & \\
\cline { 1 - 1 } 2 & Daun tidak busuk & \\
\cline { 1 - 1 } 3 & Daun tidak bercak kecoklatan & \\
\hline 4 & Tidak berbatang & \\
\hline 5 & Tidak etiolasi & \\
\hline 6 & Tidak berakar & \\
\hline 7 & Tidak dicuci & \\
\hline 8 & Panjang $35-45 \mathrm{~cm}$ & \\
\hline
\end{tabular}

\section{HASIL DAN PEMBAHASAN}

\section{Kebutuhan Air Tanaman secara Teoritis}

Yayasan Bina Sarana Bakti yang terletak di Cisarua berada pada garis lintang $06^{\circ} \mathrm{C}$, garis bujur $106^{\circ} \mathrm{C}$ BT dengan ketinggian $920 \mathrm{~m}$ di atas permukaan laut. Perhitungan kebutuhan air tanaman secara teoritis (ETc) dilakukan dengan tahapan berikut :

1. Berdasarkan data Badan Meteodologi Klimatologi dan Geofisika (BMKG) Citeko Bogor ratarata suhu maximum pada bulan Maret $201528,6^{\circ} \mathrm{C}$ dan data suhu rata-rata minimum pada bulan Maret $17,0^{\circ} \mathrm{C}$, maka

$$
\begin{aligned}
\mathrm{T} & =(\operatorname{Tmax}+\mathrm{Tmin}) / 2 \\
& =(28,6+17,0) / 2 \\
& =22,8^{\circ} \mathrm{C}
\end{aligned}
$$

2. Pada tabel $\mathrm{p}$ garis lintang $6^{\circ} \mathrm{LS}$ pada bulan Maret diperoleh $\mathrm{p}=0,28$, maka

$$
\mathrm{f}=\mathrm{p}(0.46 \mathrm{~T}+8)
$$




$$
\begin{aligned}
& =0,28(0,46 \times 22,8+8) \\
& =0,28 \times 18,5 \\
& =5,18
\end{aligned}
$$

3. Berdasarkan data BMKG Citeko Bogor pada bulan Maret 2015 kelembapan udara relatif $(\mathrm{RH})=$ $63 \%$ termasuk ke dalam kategori Tinggi > 50\% (Tabel 1).

4. Berdasarkan data BMKG Citeko Bogor pada bulan Maret 2015 lama penyinaran matahari aktual (n) $=8,2 \mathrm{jam}$.

5. Berdasarkan Tabel $\mathrm{N}$ pada garis lintang $6^{\circ} \mathrm{LS}$ pada bulan Maret diperoleh lama penyinara maksimum yang mungkin terjadi $(\mathrm{N})=12,1$ jam, maka $\mathrm{n} / \mathrm{N}=8,2 / 12,1=0,68$ tergolong kategori sedang (Tabel 1).

6. Berdasarkan data BMKG Citeko Bogor pada bulan Maret 2015 kecepatan angin (U2) 1 knots = $0,514 \mathrm{~m} / \mathrm{dt}$ tergolong kategori rendah $<2 \mathrm{~m} / \mathrm{dt}$ (Tabel 1).

7. Data RH tinggi, $\mathrm{n} / \mathrm{N}$ sedang, $\mathrm{U} 2$ rendah, dan nilai $\mathrm{f}=5,18$ maka pada Gambar pendugaan ETo metode Blaney Criddle Blok VI diperoleh ETo $=3,5 \mathrm{~mm} / \mathrm{hari}$.

8. Koefisien tanaman $(\mathrm{kc})$ didefinisikan sebagai perbandingan antara besarnya evapotranspirasi maksimum (ETm) tanaman dengan evapotranspirasi potensial pada kondisi pertumbuhan tanaman yang tidak terganggu. Nilai koefisien tanaman selada rata-rata dari setiap tahap pertumbuhan $(0,45+0,60+1,00) / 3=0,68$, dengan demikian nilai ETc dapat dihitung sebagai berikut:

$$
\begin{aligned}
\text { ETc } & =\mathrm{kc} \times \text { ETo } \\
& =0,68 \times 3,5 \\
& =2,38 \mathrm{~mm} / \text { hari } \\
& =0,00238 \mathrm{~m} / \text { hari }
\end{aligned}
$$

Lebar (L) bedengan $1 \mathrm{~m}$, panjang $(\mathrm{P})$ bedengan $10 \mathrm{~m}$, dan umur tanaman selada dalam 1 musim 30 hari maka ETc dalam 1/bedengan/musim sebagai berikut:

$$
\begin{aligned}
\text { ETc } & =\text { ETc } \times \mathrm{L} \times \mathrm{P} \times 30 \\
& =0,00238 \times 1 \times 10 \times 30 \\
& =0,714 \mathrm{~m}^{3} / \text { bedengan } / \text { musim } \\
& =714 \mathrm{1} / \text { bedengan } / \text { musim. }
\end{aligned}
$$

Jadi kebutuhan air tanaman selada secara teoritis dalam satu bedengan 714 1/bedengan/musim, jika dalam 1 bedengan rata-rata 250 batang tanaman selada maka ETc tanaman selada dalam setiap batang tanaman selada ialah $714 / 250=2,861 /$ tanaman/musim dan ETc tanaman selada perhari ialah $2,86 / 30=0,095$ l/tanaman/hari $=95 \mathrm{cc} / \mathrm{hari} / \operatorname{tanaman}$. 


\section{Jumlah Pemakaian Air Irigasi}

Perhitungan jumlah pemakaian air pada tanaman selada selama 1 musim tanam dapat dihitung dengan menjumlahkan seluruh total pemakaian air disetiap minggu pada masing-masing perlakuan dengan selang waktu yang berbeda.

1. Perhitungan jumlah pemakaian air pada perlakuan selang waktu irigasi 3 hari dilahan terbuka di bawah naungan sebagai berikut:

Total pemakaian air $=$ Minggu $1+$ Minggu $2+$ Minggu $3+$ Minggu 4

$$
\begin{aligned}
& =155+160+235+110 \\
& =660 \mathrm{l} / \text { bedengan } / \text { musim }
\end{aligned}
$$

Jumlah pemakaian air tanaman selada di lahan terbuka di bawah naungan dengan perlakuan selang waktu irigasi 3 hari sebesar 660 1/bedengan/musim, jika ditambahkan dengan air urine kelinci bercampur air sebanyak 60 liter sebagai tambahan pupuk organik ke dalam bedengan tanaman maka total pemakaian air menjadi 720 1/bedengan/musim hampir sama dengan kebutuhan air tanaman selada secara teoritis sebesar 714 1/bedengan/musim.

2. Perhitungan jumlah pemakaian air pada perlakuan selang waktu irigasi 4 hari dilahan terbuka tanpa naungan sebagai berikut:

Total pemakaian air $=$ Minggu $1+$ Minggu $2+$ Minggu $3+$ Minggu $4+$ Curah Hujan

Curah hujan selama pemeliharan tanaman selada $=446 \mathrm{~mm}=0,446 \mathrm{~m}$ dikonversi kedalam satuan 1/bedengan sebagai berikut:

$$
\begin{aligned}
& =0,446 \mathrm{~m} \times 1 \times 10 \\
& =4,46 \mathrm{~m} / \text { bedengan } / \text { musim } \\
& =4.4601 / \text { bedengan } / \text { musim. } \\
\text { Total pemakaian air } & =90+130+160+80+4.460 \\
& =4.9201 / \text { bedengan } / \text { musim }
\end{aligned}
$$

Jadi total jumlah pemakaian air + pupuk cair berupa air urine kelinci bercampur air sebanyak 60 liter pada tanaman selada di lahan terbuka tanpa naungan sebesar 4.980 1/bedengan/musim adalah sangat tidak efisien karena jauh lebih besar dibandingkan dengan kebutuhan air teoritis yang hanya sebesar 714 1/bedengan/musim.

\section{Produksi}

Rata-rata produksi selada pada kedua selang waktu irigasi dapat dilihat pada Tabel 3.

Tabel 3. Hasil Produksi tanaman selada selama 1 kali musim tanam

\begin{tabular}{cccc}
\hline \multirow{2}{*}{ No } & $\begin{array}{c}\text { Perlakuan selang waktu } \\
\text { irigasi (hari) }\end{array}$ & \multicolumn{2}{c}{ Produksi } \\
\cline { 3 - 4 } & 3 & $\mathrm{~kg} /$ bedengan/musim & $\mathrm{g} /$ tanaman \\
\hline 1 & 4 & $24,7 \mathrm{a}$ & $121,6 \mathrm{a}$ \\
\hline 2 & 4 & $98,8 \mathrm{~b}$ \\
\hline \multicolumn{2}{c}{ Keterangan: Angka pada lajur yang sama diikuti oleh huruf yang berbeda } \\
menunjukkan berbeda nyata pada uji t taraf nyata $5 \%$
\end{tabular}


Tabel 4 menunjukan bahwa produksi selada pada selang waktu pemberian air irigasi 3 hari pada lahan terbuka dengan naungan lebih tinggi dibandingkan dengan selang waktu pemberian air irigasi 4 hari pada lahan terbuka tanpa naungan, meskipun jumlah pemberian/pemakaian air irigasi pada tanaman selada selang waktu irigasi 3 hari hanya 720 1/bedengan/musim jauh lebih kecil dibandingkan dengan selang waktu irigasi 4 hari yang mencapai 4.920 l/bedengan/musim.

Hal ini terjadi karena aerasi di daerah perakaran tanaman selada pada selang waktu irigasi 3 hari berjalan lancar, sedangkan pada selang waktu irigasi 4 hari di lahan terbuka tanpa naungan aerasi kurang lancar karena tanah di daerah perakaran sering jenuh akibat guyuran hujan. Produksi selada Romain organik dengan selang waktu irigasi 3 hari pada lahan terbuka dengan naungan di Yayasan Bina Sarana Bakti Cisarua Bogor rata-rata 121,6 g/tanaman tergolong tinggi hampir sama dengan produksi selada Romain yang dilaporkan oleh Arismunandar (2019) dengan produksi ratarata $124,0 \mathrm{~g} /$ tanaman.

\section{Produktivitas Air Irigasi Tanaman Selada}

Produktivitas air irigasi tanaman selada Romain pada selang waktu yang berbeda dapat dilihat pada Tabel 4.

Tabel 4. Produktivitas air tanaman selada selama musim tanam.

\begin{tabular}{cccc}
\hline $\begin{array}{c}\text { Perlakuan selang waktu } \\
\text { Irigasi (hari) }\end{array}$ & $\begin{array}{c}\text { Produksi } \\
\mathrm{kg} / \text { bedengan }\end{array}$ & $\begin{array}{c}\text { Pemakaian air } \\
\left(\mathrm{m}^{3} / \text { bedengan }\right)\end{array}$ & $\begin{array}{c}\text { Produktivitas air } \\
\left(\mathrm{kg} / \mathrm{m}^{3}\right)\end{array}$ \\
\hline 3 & 30,4 & 0,720 & $42,22 \mathrm{a}$ \\
\hline 4 & 24,7 & 4,980 & $4,96 \mathrm{~b}$ \\
\hline
\end{tabular}

Keterangan: Angka pada lajur yang sama diikuti oleh huruf yang berbeda menunjukkan berbeda nyata pada uji t taraf nyata $5 \%$

Tabel 4 menujukkan bahwa produktivitas air tanaman selada Romain pada perlakuan selang waktu irigasi 3 hari di lahan terbuka dengan naungan 42,22 kg/m $\mathrm{m}^{3}$ sangat jauh lebih tinggi dibandingkan dengan perlakuan selang waktu irigasi 4 hari di lahan terbuka tanpa naungan. Bahkan juga lebih tinggi dibandingkan dengan produksitivitas air tanaman selada Romain hidroponik yang menggunakan metode Nutrient film technique (NFT) yang dilaporkan oleh Arismunandar (2019) dengan produktivitas air sebesar 12,23 kg/m³ . Hal ini juga menunjukkan bahwa selang waktu irigasi 3 hari pada tanaman selada Romain organik di lahan terbuka dengan naungan sangat efisien dan efektif untuk mempertahankan produktivitas tanaman selada.

\section{KESIMPULAN}

Dalam penelitian ini dapat disimpulkan:

1. Selang waktu irigasi dalam budidaya organik tanaman selada di Yayasan Bina Sarana Bakti Cisarua Bogor berpengaruh nyata terhadap jumlah pemakaian air, produksi dan produktivitas air tanaman selada. 
2. Jumlah kebutuhan air tanaman selada secara teoritis di Yayasan Bina Sarana Bakti sebesar 714 1/bedengan/musim hampir sama dibandingkan dengan jumlah pemakaian air aktual tanaman selada dengan selang waktu irigasi 3 hari di lahan terbuka dengan naungan,yaitu sebesar 720 1/bedengan/musim, namun jauh lebih kecil dibandingkan dengan jumlah pemakaian air tanaman selada dengan selang waktu irigasi tanpa naungan yaitu 4.980 l/bedengan/musim.

3. Produksi tanaman selada dalam naungan dengan selang waktu 3 hari sebesar $30,4 \mathrm{~kg} /$ bedengan/ musim lebih besar dibandingkan dengan tanaman selada tanpa naungan dengan selang waktu pemberian air irigasi 4 hari, yaitu sebesar $24,7 \mathrm{~kg} /$ bedengan $/$ musim.

4. Produktivitas air irigasi untuk tanaman selada dalam naungan dengan pemberian air irigasi selang waktu 3 hari sebesar $42,22 \mathrm{~kg} / \mathrm{m}^{3}$ lebih tinggi dan lebih efekif dibandingkan dengan tanaman selada tanpa naungan dengan pemberian air selang waktu 4 hari yang hanya sebesar $4,96 \mathrm{~kg} / \mathrm{m}^{3}$.

\section{DAFTAR PUSTAKA}

Arismunandar. 2019. Pemakaian Air Nutrisi pada Berbagai Varietas Tanaman Selada dengan Menggunakan Sistem Irigasi Nutrient Film Technique (NFT) di PT Momenta Agricultura Lambang Bandung Barat. Laporan Tugas Akhir. Politeknik Negeri Lampung. Bandar Lampung.

Idrus, M. 2013. Disain Irigasi Tetes Tipe Orifis Tanpa Pompa Untuk Tanaman Slada Secara Hidroponik Pada Rak-Rak Bertingkat. Jurnal Ilmiah Teknik Pertanian TekTan ISSN 2085-1278 Volume 5 No. 1, April 2013.

Pracaya, 2002. Bertanam Sayuran Organik. Penebar Swadaya. Jakarta.

Rukmana, R.1994.Bertanam Selada dan Andewi. Kanisius.Yogyakarta.

Sastradiharja, 2011. Sukses Bertanam Sayuran Organik. Angkasa.

Supriati, Y. dan E. Herlina. 2010. Bertanam Lima Belas Sayuran dalam Pot. Penebar Swadaya. Bogor.

Widiasari. 2015. Pemakaian Air Beberapa Varietas Selada Dengan Aplikasi Sistem Irigasi NFT (Nutrient Film Technique) Di PT. Momenta Agrikultura Lembang Bandung Barat. Laporan Tugas Akhir. Politeknik Negeri Lampung. Bandar Lampung. 